\title{
Influence of Endocarp Thickness on Rose Achene Germination: Genetic and Environmental Factors
}

\author{
Serge Gudin and Laurence Arene \\ Sélection Meilland, 134 Bd. Francis Meilland, Antibes 06600, France
}

\author{
André Chavagnat \\ I.N.R.A. Angers, Centre de Recherches Agronomiques d'Angers, \\ Beaucouzé, Angers 49000, France \\ Camille Bulard \\ Laboratoire de Physiologic Végétale, University de Nice, 28 av. de \\ Valrose, Nice 06034, France \\ Additional index words. Rosa hybrids, seed radiography, pericarp, true seed, embryo
}

\begin{abstract}
Rose achenes of different genetic origins, all belonging to the species Rosa hybrids L., subjected to radiography films, germination tests, in situ observations of embryo development, and different temperature conditions during maturation showed that achene germination is affected by endocarp thickness. Furthermore, a relation between embryo development rate and endocarp thickness is demonstrated.
\end{abstract}

A rose achene is composed of pericarp epi-, meso-, and endocarp layers; the last structure is particularly impermeable to the imbibition of water (unpublished data). The endocarpic layer might therefore represent a physical obstacle, of the tegument type, to achene germination. Gutterman and Heydecker (1973) have shown that, in Ononis sicula seed, tegument thickness determined tegument permeability and seed germination quality differences. More recently, Nerson et al. (1985) demonstrated a relation between seed germination and tegument thickness in Citrullus lanatus.

The seed mother plant environment is liable to influence tegument permeability and/ or thickness of various seeds. In Ononis sicula and Trigonella arabica, lighting has been shown to play a decisive role (Evenari et al., 1966; Jacques, 1968; Gutterman, 1978). Influence of temperature during seed development on germination has often been demonstrated. It is known that, generally, seeds produced by mother plants cultivated in a range of 18 to $24 \mathrm{C}$ germinate better than those produced at $15 \pm 2 \mathrm{C}$. This has been shown in Lactuca sativa (Barrington and Thompson, 1952), Aegilops ovata (Datta et al., 1972), Silene inflata and Alyssoides utriculatum (Dome, 1973a), Chenopodium Bonus Henricus (Dome, 1973b; Dome and Come, 1976). In Rosa hybrida, Von Abrams and Hand (1956) demonstrated a beneficial influence of relatively high temperatures during achene maturation on germination. With the same species, De Vries and Dubois (1987) recently showed, by cultivating the mother plants at constant temperatures in a

Received for publication 23 Oct. 1989. The cost of publishing this paper was defrayed in part by the payment of page charges. Under postal regulations, this paper therefore must be hereby marked advertisement solely to indicate this fact. phytotron, that relatively high temperatures (22 and 26C) had a favorable influence on achene germination, as compared to lower temperatures $(10,14$, and $18 \mathrm{C})$.

We determined whether endocarp thickness of rose achenes influences seed germination and whether a relation could be demonstrated between the thickness of this layer and the genetic origin of the achenes or temperature during maturation. It is wellknown that temperature influences the rate of embryo development, and the beneficial effect of warm environments on embryo development among Rosaceae has already been shown in plum (Thompson and Liu, 1973) and cherry (Braak, 1978). We therefore also looked for a possible correlation between the rate of embryo development and the thickness of the mature achene endocarp.

Only achenes having a density greater than 1 , selected according to the flotation method described by Taylor et al. (1982), were used. They resulted from four different crosses among cultivars of Rosa hybrida. Two of these crosses were first carried out in Mar. 1987 and repeated in May 1987, flowers being produced in the same greenhouse at Selection Meilland, Antibes. The other two crosses, using the same cultivar as female parent, were carried out on the same day in May 1986. The achenes used for germination tests were collected 4 months after pollination.

Ovule and embryo development were observed during maturation of achenes issued from one identical crossing carried out in Mar. and May 1987 and from two different crosses carried out in May 1986.

Crosses and maturation conditions. The flowers of the cultivars chosen as female parents were always sampled at the morphological stage corresponding to commercial cropping stage. They were emasculated, covered with a transparent paper cone (Chrystal $6 \times 10$ avec patte), and, $48 \mathrm{hr}$ 
later, pollinated with a paint brush (Raphael no. 8 ). The pollen was produced by the dehiscence of anthers kept $48 \mathrm{hr}$ in glass cupels (Duralex, diameter $9 \mathrm{~cm}$ ) in the laboratory.

Temperature and hydrometry were recorded (thermo-hygrograph, Jules Richard et Pekly NG 5538) during development of the hips containing achenes.

Germination tests. Each test was carried out with 500 achenes. In each case, before sowing, achenes were stratified for 1 month at $23 \mathrm{C}$ and 2 months at $4 \mathrm{C}$, respectively, in darkness. After stratification, achenes were individually sown on Jiffy Seven cylinders $(\approx 0.1$ liter $)$ previously hydrated and set in plastic netting trays (96 Jiffy Seven/tray). A 1 -cm-thick, layer of vermiculite was laid down on the Jiffy Seven to cover the achenes. It was then hand watered, hydration being maintained by a weekly drench. Trays were placed in a greenhouse maintained during winter at average day-night settings of 22 and $13 \mathrm{C}$, respectively. Emergence was observed 2 months after sowing. The appearance of cotyledons above the vermiculite layer was used as the criterion of germination.

$X$-ray radiography. Radiography was carried out at I.N.R.A. Angers according to the method described by Chavagnat and Le Lezec (1984) and Chavagnat (1987). Measurements of pericarp and endocarp thicknesses and true seed section were made as described by Gudin et al. (unpublished). They were carried out on films with at least 40 freshly collected achenes per cross. Among these, at least 30 full achenes containing developed embryos were used.

Ovule and embryo development. To follow the progress of embryo development on the mother plants, 10 hips resulting from the crosses ( $R$. hybrids CV. no. 364-73. D $\times R$. hybrida $\mathrm{CV}$. Jelrafloki; $R$. hybrida $\mathrm{CV}$. Meiringa $\times R$. hybrida $\mathrm{CV}$. Meitulandi; $R$. hybrids $\mathrm{CV}$. Meiringa $\times R$. hybrida $\mathrm{CV}$. Pink Puff) were collected weekly following pollination and opened to observe the maturity stages of the achenes, fecund ovules, and embryos. Ovules isolated from ovaries were measured along their major axis at $\times 800$ under a Wild M3 binocular lens equipped with a micrometer eye piece. A few weeks after pollination, fecund ovules could be distinguished from nonfecund ones by taking into account ovary dimensions, the former being on average 1.6 times longer and 3 times wider than the latter. Ovaries that do not contain fecund ovules do not exceed a 1.5$\mathrm{mm}$ length and a 1-mm width on average. A few weeks later, after a previous dissection of developing achenes, embryos themselves became visible and were isolated under a binocular at magnification $\times 800$. The smallest visible embryos in these conditions were $0.2 \mathrm{~mm}$ long and heart-shaped.

Influence of genetic factors. Genetic origin contributes to achene germination (Table 1). The pollenizer influence is demonstrated: the endocarp of achenes resulting from the cross that has a lower terminability is, on average, 1.4 times thicker than that of the achenes of the other one.

Figure 1 also clearly shows that the cross that produces achenes with lower germination ('Meiringa' $\times$ 'Meitulandi') is characterized by a slower increase in ovule length. Since the growing conditions were similar, the genetic origin appears to be the factor determining this difference in the rate of development.

Influence of temperature. The temperature of seed mother plant environments was on average $5.5 \mathrm{C}$ higher during the 12 weeks following the May pollination than following the March pollination. The rate of increase in ovule length appears to differ according to the pollination period (March or May) in $R$. hybrida CV. no. 364-73.D $\times R$. hybrida CV. Jelrafloki (Fig. 2). Ovule development is more rapid for the maturation period following May pollination than for that following March. As a consequence, the embryos are visible earlier after May than after March pollination. Temperature is probably the principal determinate for this rate difference in development, although other climatic factors, such as irradiation, might also have an influence. The beneficial effect of a warm environment on embryo or true seed development has been demonstrated in numerous and diverse species (Le Deunff and Chaussat, 1969; Junttila, 1971; Thompson and Liu, 1973; Montegut, 1974; Braak, 1978). It is interesting to note that for equivalent reference stages, either when fecund ovules can 'be distinguished from nonfecund ones or when embryos become visible under a binocular lens, the ovule dimensions do not differ $(P$ $=0.05$; Student's $t$ test), regardless of maturation conditions (after May or March pollination). This fact agrees with results of Junttila (1971), who reported that dry weights of mature lilac seeds are only very slightly different according to different production temperatures. Prunus avium embryos submitted to diverse environments during maturation reach similar dimensions when fully mature (Braak, 1978). This author also showed that environmental temperature influence on embryo development rate is maximal at transition from "phase I" to "phase H" (Tukey, 1933). The first stage essentially corresponds to pericarp and nucellus development, whereas the second one corresponds to rapid embryo growth accompanied by endocarp hardening.

Achenes of identical genetic origin that matured after March or May pollination did

Table 1. Germination and pericarp and endocarp thickness of achenes of two hybrid rose crosses.

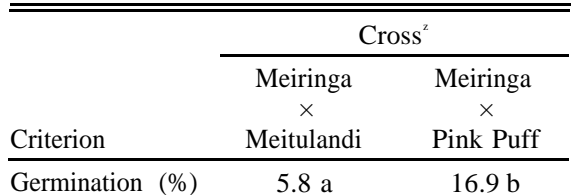

Pericarp

thickness (mm) $2.88 \pm 0.5$ a $2.76 \pm 0.68$ a Endocarp

thickness (mm) $1.04 \pm 0.19$ a $0.74 \pm 0.13$ b

${ }^{2}$ Percentages or means $( \pm$ SD) followed by an identical letter, on the same line, are not significantly different from each other at $P=0.05$ ( $\mathrm{x}^{2}$ and Pearson's conformity tests), 50 observations per cross.

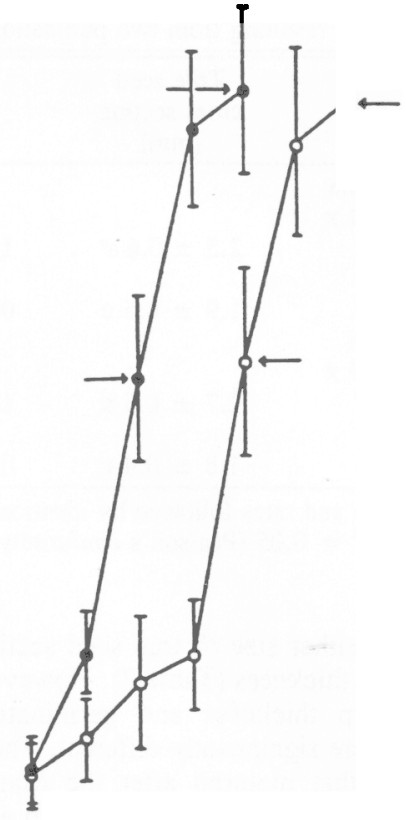

Fig. 1. Ovule length of 'Meiringa' $\times$ 'Meitulandi' ( $O$ ) or $\times$ 'Pink Puff' $(\bullet)$ roses until embryos are "visible". For both curves, the first arrow signals the time when the difference between fecund and nonfecund ovules becomes noticeable; the second signals the time when embryos are visible.

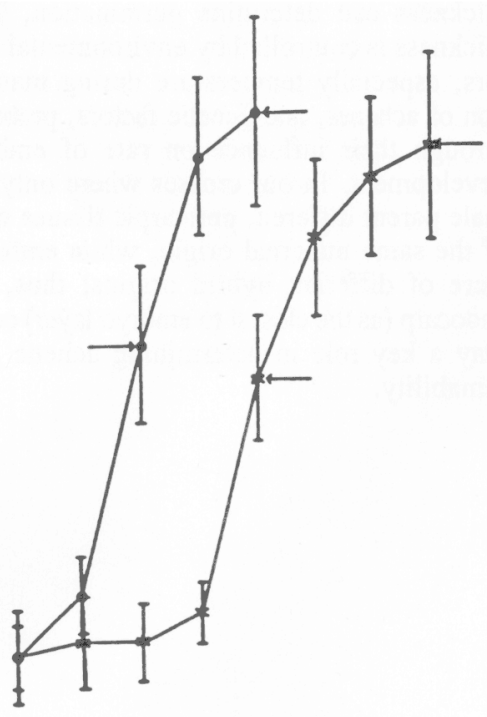

Fig. 2. Ovule length of no. 364-73.D $\times$ 'Jelrafloki' from May ( $\bullet$ ) or March (*) pollinations until embryos are "visible". For both curves, the first arrow signals the time when the difference between fecund and nonfecund ovules becomes noticeable; the second signals the time when embryos are visible. 
Table 2. True rose seed pericarp and endocarp measurements and germination of achenes of two genetic origins resulting from two pollination periods.

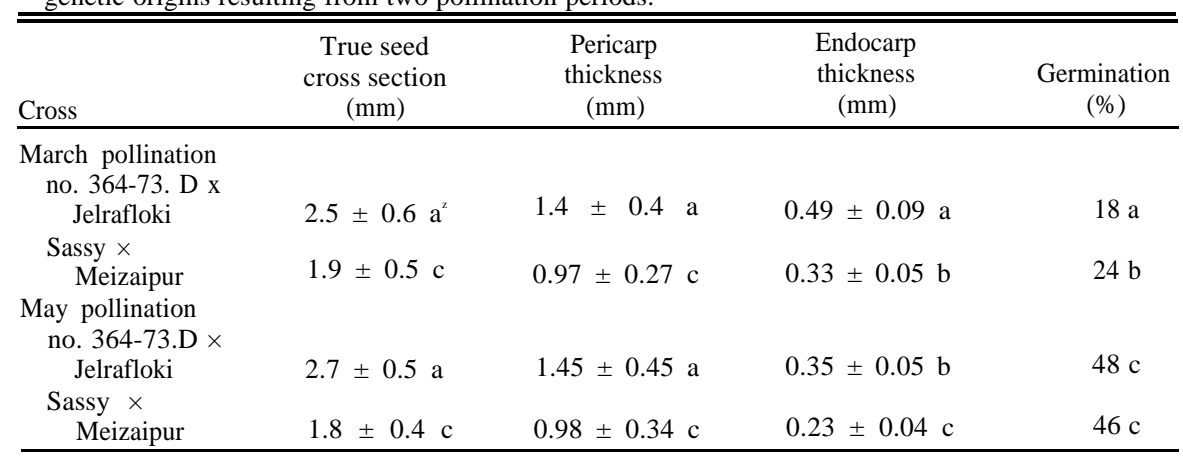

${ }^{2}$ Means (k SD) and rates followed by identical letters in a column are not significantly different from each other at $P=0.05$ (Pearson's conformity and $x^{2}$ tests) 30 observations per cross and pollination period.

not differ in either size of true seed section or in pericarp thickness (Table 2). However, both endocarp thickness and germination percentage were significantly different. Thus, the achenes that matured after the March pollination had both a thicker endocarp and lower germination than those that matured after May.

Our results demonstrate that the barrier presented by the endocarp is determined during true seed early development; the slower this development is, the more germination will be limited. We hypothesize that competition probably exists between true seed development rate and thickness of the physical barrier represented by the endocarp. Nitsch (1951) has already noted such a competition between developing seeds and ovary tissues in tomato, and Norstog (1961) observed a similar phenomenon in barley.

The results presented above clearly show that in a rose achene pericarp, the endocarp thickness can determine germination. This thickness is controlled by environmental factors, especially temperature during maturation of achenes, and genetic factors, probably through their influence on rate of embryo development. In our crosses where only the male parent differed, pericarpic tissues were of the same maternal origin, while-embryos were of different hybrid origins; thus, the endocarp (as the closest to embryo layer) could play a key role in determining achene germinability.

\section{Literature Cited}

Braak, J.P. 1978. The effect of flowering date and temperature on embryo development in sweet cherry. Netherlands J. Agr. Sci. 26:13-30.

Chavagnat, A. 1987. Use of soft X-ray radiography for studying seed quality in horticulture. Acta Hort. 215:153-158.

Chavagnat, A. and M. Le Lezec. 1984. Détermination de la valeur culturale des semences par la radiographic industrielle aux rayons X. Application aux pépins de pommiers. Agronomic 5:187-197.

Datta, S. C., Y; Gutterman, and M. Evenari. 1972. The influence of the origin of the mother plant on yield and germination; of their caryopses in Aegilops ovata. Planta 105:155-164.

De Vries, D.P. and L. Dubois. 1987. The effect of temperature on fruit set, seed set and seed germination in "SONIA" $\times$ "HADLEY" hybrid tea-rose crosses. Euphytica 36:117-120.

Dorne, A.J. 1973a. Germination de deux espèces à large distribution altitudinale: Silene inflata et Alyssoides utriculatum. Influence, sur le comportement germinatif, de la culture des portegraines à basse altitude. Phyton 31:25-39.

Dorne, A.J. 1973b. Influence de l'altitude de récolte sur la capacité de germination des semences du Chenopodium Bonus Henricus L. Comp. Rend. Acad. Sci. Paris 277:305-308.

Dorne, A.J. and D. Come. 1976. Germination des semences du Chenopodium Bonus Henricus L. Recherche du mécanisme de l'inaptitude à la germination des semences récoltés à une altitude élevée. Biological Plant. 18:72-77.

Evenari, M., D. Keller, and Y. Gutterman. 1966. Effects of the environment of the mother plant on germination by control of seed coat perme- ability to water in Ononis sicula Guss. Austral. J. Biol. Sci. 19:1007-1016.

Gutterman, Y. 1978. Seed coat permeability as a function of photoperiodical treatments of the mother plants during seed maturation in the desert annual plant: Trigonella arabica. J. Arid Env. 1:141-144.

Gutterman, Y. and W. Heydecker. 1973. Studies of the surfaces of desert plant seeds. I. Effect of day length upon maturation of the seed coat of Ononis sicula Guss. Ann. Bot. 37:1049-1050.

Barrington, J.F. and R.C. Thompson. 1952. Effect of variety and area of production on subsequent germination of lettuce seed at high temperatures. Proc. Amer. Soc. Hort. Sci. 59:445-450.

Jacques, R. 1968. Action de la lumière par l'intermédiaire du pytochrome sur la germination, la croissance et le développement de Chenopodium polyspermum L. Physiol. Vég. 6:137164.

Junttila, O. 1971. Effect of mother plant temperature on seed development and germination in Syringa reflexa Schneid. Inst. of Dendrolody and Nursery Management, Agr. College of Norway. Rpt. 38:50:1-16.

Le Deunff, Y. and R. Chaussat. 1969. Remarques concernant- les exigences germinative de $R u$ mex sp. Colloque sur la biologic des mauvaises herbes. Comp. Rend. du Colloque, Guyot Ed., Grignon 78, France.

Montegut, J. 1974. Ecologic de la germination des mauvaises herbes. Germination des semences. Gauthier-Villars, Paris. p. 193-215.

Nerson, H., H.S. Paris, Z. Karchi, and M. Sachs. 1985. Seed treatments for improved germination of tetraploid watermelon. HortScience 20:897-899.

Nitsch, J.P. 1951. Growth and development in vitro of excised ovaries. Amer. J. Bot. 38:566577.

Norstog, K. 1961. The growth and differentiation of cultured barley embryos. Amer. J. Bot. 48:876-884.

Taylor, A. G., A.M. MacCarthy, and E.M. Chirco. 1982. Density separation of seeds with hexane and chloroform. J. Seed Techol. 7:78-83.

Thompson, M.M. and L.J. Liu. 1973. Temperature, fruit set and embryo sac development in 'Italian' prune. J. Amer. Soc. Hort. Sci. 98:193197.

Tukey, H.B. 1933. Artificial culture of sweet cherry embryos. J. Hered. 24:7-12.

Von. Abrams, G.J. and N.E. Hand. 1956. Seed dormancy in Rosa as a function of climate. Amer. J. Bot. 43:7-12. 